\title{
THE FRANCHISE DILEMMA: \\ ENTREPRENEURIAL CHARACTERISTICS, RELATIONAL CONTRACTING, AND OPPORTUNISM IN HYBRID GOVERNANCE
}

\author{
Heiner Evanschitzky \\ Barbara Caemmerer \\ Christof Backhaus
}

Paper accepted for publication at the Journal of Small Business Management doi: 10.1111/jsbm.12145 
The Franchise Dilemma: Entrepreneurial Characteristics, Relational Contracting, and Opportunism in Hybrid Governance*

Heiner Evanschitzky, Barbara Caemmerer, Christof Backhaus

Using a matched sample of franchisee and franchisor data, we identify through hierarchical linear modeling (HLM) that entrepreneurial characteristics of franchisees partially impact on their opportunistic tendencies. Further, relational contracting increases franchisee opportunism by strengthening the opportunism-enhancing impact of entrepreneurial characteristics. These findings point to a key dilemma franchisors need to be aware of: Entrepreneurially minded franchisees who might be better at exploiting market opportunities for their units may also behave more opportunistically, if given the chance through a more relational contracting regime. At the same time, if they perceive the contractual framework as being too rigid, they may be less able to leverage their capabilities, become dissatisfied and exit the system.

\section{Acknowledgments}

The authors thank Gary J. Castrogiovanni, Colin Mason, and Josef Windsperger who commented on earlier versions of the manuscript.

Heiner Evanschitzky is Professor of Marketing at Aston University, Birmingham, UK.

Barbara Caemmerer is Professor of Marketing at ESSCA School of Management and LUNAM University, France.

Christof Backhaus is Assistant Professor of Services Management at the Technische Universität Braunschweig, Germany.

Address correspondence to: Heiner Evanschitzky, Professor of Marketing, Aston University, Marketing Group, Aston Triangle, Birmingham B4 7ET, UK, h.evanschitzky@aston.ac.uk. 


\section{Introduction}

The choice of organizational governance form is a key strategic management decision as it has long-term implications on firm performance (Mitsuhashi, Shane, and Sine 2008; Sorenson and Sorensen 2001). A leading perspective in governance form choice is transaction cost economics (TCE), which holds that organizations will handle transactions to minimize the costs involved in carrying them out (Williamson 1985, 1991, 2010). Increasingly, organizations turn to hybrid forms of governance to have greater control than in market exchange, and to avoid disadvantages associated with vertical integration (Norton 1988; Powell 1990; Yin and Zajac 2004).

In particular, franchising as a hybrid governance model has gained increased economic importance and research attention over the last three decades (e.g., Blut et al. 2011; Castrogiovanni, Combs, and Justis 2006; Hunt 1977; Kaufmann and Dant 1999; Kaufmann and Rangan 1990; Kidwell and Nygaard 2011; Nair, Tikoo, and Liu 2009; Tracey and Jarvis 2007; Windsperger and Dant 2006). Franchising is particularly common in sectors where organizations need to operate through diffused distribution networks with outlets that are located close to customers and managed by individuals with local knowledge (Berg and Friedman 1980; Blair and Lafontaine 2005; Carney and Gedajlovic 1991).

The benefits of franchising in comparison to other channel relationships are rooted in the unique combination of two functional principles: On the one hand, integrating a network of outlets under one brand and unified operational policies allows for capitalizing on economies of scale (Shane 1996). On the other hand, successful franchising depends on autonomously acting franchisees able to adapt to local market conditions and capitalize on the benefits of entrepreneurial engagement at a micro-system level (Sorenson and Sorensen 2001). Certainly, 
other hybrid forms of organization such as cooperative purchasing groups or licensing agreements might possess similar advantages; yet, franchising is probably the most visible hybrid form of governance and hence the focus of this paper.

Given the apparent tension between the two aforementioned functional principles, franchise relationships are fragile and in need of balancing standardization and adaptation (Sorenson and Sorensen 2001) as well as autonomy and dependence (Dant and Gundlach 1999). To find that balance, franchising crucially depends on both, the proper selection (ex-ante) as well as the management of franchisees (ex-post) (Jambulingam and Nevin 1999; Michael and Combs 2008).

However, two key assumptions of TCE, bounded rationality and opportunism, advocate a focus on the contracting of partners. As a consequence, research has in the main focused on appropriate contracting so as to minimize levels of opportunism and related transaction costs (e.g., Mitsuhashi, Shane, and Sine 2008; Sorenson and Sorensen 2001; Yin and Zajac 2004). While the limitations of formal contracting have been well established in the literature (e.g., Aulakh and Gençtürk 2007; Poppo and Zenger 2002; Tirole 1999), less is known about the conditions under which relational contracting is an effective way of safeguarding against negative outcomes such as opportunism. This is important, though, as there is evidence that this form of contracting is being increasingly used in franchise systems to confront problems with agents (Cochet, Dormann, and Ehrmann 2008).

Neoclassical contract theory suggests that formal and more extensive contracting efforts help to safeguard against opportunism (Luo 2002). The reason for this is that formal contracts explicitly state how members should behave, which leaves little room for interpretation of the rules outlined in the contract (Lusch and Brown 1996). As a result, sanctioning against misconduct is relatively straight forward. 
In contrast, sociological approaches to contracting emphasize to a greater extent relational forms of contracting (Carson, Madhok and Wu 2006). Relational contracting incorporates the use of "unwritten codes of conduct" (Davies et al. 2011, p. 325) to safeguard against negative relationship outcomes (Cochet, Dormann, and Ehrmann 2008). In this type of contracting implicit, "relational norms that govern acceptable behavior between exchange partners" (Lusch and Brown 1996, p. 19) are developed over time and are based on social consensus or mutual understanding. Thus, relational contracting is long-term-oriented, reciprocal, and extends beyond mere buying and selling (Li and Dant 1997), as it forms the basis for the development of shared, long-term relational norms and behaviors between partners. Within a given franchise system, franchisors generally exercise the same level of relational contracting. Differences in levels of relational contracting are more based on perceptions of franchisees than on franchisor conduct.

The key relational norms and behaviors that have been widely acknowledged in the literature are flexibility, information exchange, and collegiate problem-solving (Heide and John 1992; Kaufmann and Stern 1988; Poppo and Zenger 2002). As these norms develop in franchising contexts between franchisees and their franchisor over time, relational contracting can be regarded as a system level behavioral variable, which is likely to differ across systems, rather than a channel design variable (Hoetker and Mellewigt 2009). As such, in relational contracting social forces may create barriers to opportunistic behavior and foster cooperation (Carson, Madhok and Wu 2006). For these reasons it has been argued that relational contracting may create economic value (Brown, Dev, and Lee 2000).

It has been acknowledged that the two described types of contracting, formal and relational, often coexist in organizational environments, i.e. they are not mutually exclusive (Lusch and Brown 1996). The extent to which one or the other is used depends on the situation and the 
assessment as to what type of contracting is more efficient, i.e. which one can better safeguard against opportunism in a given business context (Carson, Madhok and Wu 2006).

Although some studies suggest that relational contracting is efficient (Birkeland 2002; Lado, Dant, and Tekleab 2008), there is also evidence that its efficiency is dependent on organizational governance form, and in particular the level of ambiguity pertinent within organizations. Ambiguity (e.g., Sillince, Jarzabkowski and Shaw 2010) refers to the possibility that an interpretation of a situation, information or role is doubtful or uncertain. The pertinence of ambiguity in principal-agent relationships, as can be found in hybrid governance forms such as franchising, has been well acknowledged in the literature (Kashyap, Antia and Frazier 2012). In the main, ambiguity can be observed in the form of franchisee role ambiguity, for example in relation to what functions or responsibilities the franchisee needs to fulfill in a franchise system.

Agency theory highlights the issues that arise with the principal (franchisor) employing an agent (franchisee). According to agency theory, complete formal contracts can be formulated in order to control agent actions. However, TCE assumes that such contracts are necessarily incomplete (e.g., Williamson 1975, 1985), which in turn gives room for interpretation, for example in relation to the functions and responsibilities of the franchisee. This, by definition, means that ambiguity is higher in franchising contexts with principal and agent relationships than in hierarchy, as company-owned units are under stronger, explicit control and have fewer possibilities for own decision-making (Yin and Zajac 2004).

Further, based on the extant literature, there is also reason to suggest that agent motivation can impact on the safeguarding effects of relational contracting in franchising: From an agency theory perspective (Eisenhardt 1989; Gillis et al. 2011), franchisors (principals) have to consider the motivations of the individual franchisee (agent) before determining contractual arrangements 
(Michael and Combs 2008). However, little research has been carried out to investigate the combined effects of contracting and agent motivation on opportunism.

Franchisees are frequently referred to as legally independent, small scale entrepreneurs (Cochet and Garg 2008). While there is some debate as to whether franchisees actually are entrepreneurs (Ketchen, Short, and Combs 2011) and possess entrepreneurial characteristics (Birkeland 2002), there is growing support for the notion (Cochet, Dormann, and Ehrmann 2008; Kaufmann and Dant 1999), whether they are in single-unit or sequential multi-unit agreements (Ketchen, Short, and Combs 2011; Grünhagen and Mittelstaedt 2005).

Here exactly lies the franchising dilemma which is the focus of our study: On the one hand, entrepreneurial characteristics and motivations are desirable as they are related to the identification and exploitation of market opportunities for the system. To fully leverage the entrepreneurial capital franchisees bring into the system, franchisors might need to grant a certain level of autonomy (Kaufman and Eroglu 1999; Schul, Little, and Pride 1985; Strutton, Pelton, and Lumpkin 1995). On the other hand, there is reason to suggest that entrepreneurial characteristics in combination with greater autonomy may be related to higher levels of opportunism and thus increased transaction costs for the franchisor (e.g., Cochet, Dormann, and Ehrmann 2008).

As little research exists concerning the dilemma we described, we will first investigate how key entrepreneurial characteristics - innovativeness, risk-taking, and proactiveness (Miller 1983; Covin and Slevin 1986, 1989) - influence opportunistic tendencies of franchisees. Thus, in this study we consider these entrepreneurial characteristics at an individual franchisee level.

Secondly, in order to understand the extent to which relational contracting, a franchise system level variable, may or may not safeguard franchisors against agency problems in these industries, 
we assess its moderating role on the link between franchisees' propensity to favor innovation, take risks, being proactive, and opportunism in franchisee-franchisor dyads. As mentioned above, this is particularly important as there is evidence that relational contracting is increasingly adopted as a management strategy in franchising systems (Cochet, Dormann, and Ehrmann 2008).

Addressing this research agenda we add to the extant literature by highlighting some important issues that need to be considered by franchisors ex-ante in the selection, as well as expost in the management of franchisees.

\section{Theoretical Background and Hypotheses}

\section{The Franchisee-Entrepreneur Performance Dilemma}

One of the main arguments for the adoption of franchising as a hybrid governance form advanced in the literature is the problem of agent motivation (Price 1997). Due to the geographically dispersed nature of franchise systems it is difficult to oversee the actions of outlet managers. Thus, in order to reduce transaction costs associated with safeguarding against negative business outcomes, franchising is viewed as a favorable option. The commonly held view is that franchisees as owners of their outlets are more motivated to act in the interest of the business than employed managers (Castrogiovanni, Combs, and Justis 2006; Michael and Combs 2008).

Contrary to the opinion of some, franchising is often described as an entrepreneurial activity (Cochet and Garg 2008). Birkeland (2002) highlights that franchise systems do not hamper entrepreneurial motivations of their franchisees and that most franchise operations are small and run like family businesses. In line with this, many authors suggest that franchisees are 
entrepreneurs and possess entrepreneurial characteristics (Grünhagen and Mittelstaedt 2005; Kaufman and Dant 1999). Similarly, Birkeland (2002) states that franchisees think of themselves as entrepreneurs as they own their franchise unit.

Specifically, in a recent paper, Ketchen, Short, and Combs (2011) provide an in-depth discussion of the question of whether franchisees can be regarded as entrepreneurs. The authors provide compelling empirical evidence that franchisees possess entrepreneurial motivations (Ketchen, Short, and Combs 2011) which are linked to positive business outcomes. In sum, the idea that franchisees' entrepreneurial capacities are desirable and may contribute to system success is relatively uncontested.

The current state of research provides strong support for three key entrepreneurial characteristics: innovativeness, risk taking and proactiveness (Caliendo, Fossen, and Kritikos 2009; Carland et al. 1984; Covin and Slevin 1986, 1989; Delmar and Davidsson 2000; George and Marino 2011; Kaufmann and Dant 1999; Korunka et al. 2003; Miller 1983). These have been defined by Lumpkin and Dess (2001, p. 431) as follows:

Innovativeness refers to "a willingness to support creativity and experimentation in introducing new products/services, and novelty, technological leadership and R\&D in developing new processes." While innovativeness is positively linked to openness to new experience, its downside is its negative association with agreeableness and conscientiousness. It is more likely that such individuals engage in "breaking rules" and have a greater propensity to act opportunistically (George and Zhou 2001; Runco 2004). Risk taking has been defined as a "tendency to take bold actions such as venturing into unknown new markets, committing a large portion of resources to ventures with uncertain outcomes, and/or borrowing heavily" (Lumpkin and Dess 2001, p. 431). If someone is more prone to risk taking then they are more likely to take 
a gamble that they are not going to get caught when disregarding rules or norms. Thus, the risk of acting opportunistically increases (Jambulingam and Nevin 1999). Proactiveness represents an “opportunity-seeking, forward-looking perspective involving introducing new products or services ahead of the competition and acting in anticipation of future demand to create change and shape the environment" Lumpkin and Dess 2001, p. 431). As proactiveness deals with competitiveness and getting ahead of competition, opportunistic behavior is more likely as “cutting corners" seems acceptable (Kickul and Gundry 2002).

Given that the above characteristics are not necessarily strongly related to each other (Lumpkin and Dess 2001), we look at each of them separately instead of integrating them into a higher order construct, “entrepreneurial orientation” (e.g., Covin and Wales 2012; Wiklund 1999). This is in response to the suggestion from the literature stating that future research in this domain may benefit from such an approach, instead of looking at entrepreneurial orientation as an aggregate concept (Kreiser, Marino, and Weaver 2002; Lumpkin and Dess 1996).

Literature investigating consequences of entrepreneurial motivations has linked the construct to performance outcomes ( $\mathrm{Li}$, Huang, and Tsai 2009; Wiklund 1999). Consequently, also in the context of franchising, one could assume that entrepreneurial characteristics of franchisees drive their individual franchisee performance. However, there are also arguments for the notion that entrepreneurial characteristics of franchisees may, in fact, have a negative impact on franchise system performance: All three entrepreneurial characteristics under investigation - namely, innovativeness, business risk-taking, and proactiveness (Marino et al., 2002; Morris and Sexton 1996; Wiklund and Shepherd 2005) - are related to lower levels of agreeableness in work settings, higher tolerance to friction and a stronger urge for autonomy (Birkeland 2002; 
Caliendo, Fossen, and Kritikos, 2009; Eysenck 1976; George and Zhou 2001; Jambulingam and Nevin 1999; Kickul and Gundry 2002; Lumpkin, Cogliser, and Schneider 2008; Runco 2004).

Concerning innovativeness, it can be argued that this characteristic should enhance the desire for work settings that allow for personal fulfillment and the freedom to move forward with one's own ideas without any constraints imposed by the franchisor. As an entrepreneurial characteristic, innovativeness should thus correspond with an increased interest to implement own ideas in order to positively influence own store performance (Combs, Michael, and Castrogiovanni 2004; Bradach 1997; Kaufmann and Eroglu 1999). Given that, at least to some extent, franchise systems naturally restrict personal initiatives and freedom to realize innovative ideas, it can be assumed that innovativeness does not necessarily correspond with cooperative behavior, but may instead foster opportunistic tendencies. Franchisees with higher levels of risktaking are more prone to "challenge the way business is conducted" (Jambulingam and Nevin 1999) by their franchisor. In such cases there may be a greater propensity to engage in divergent activities in order to enhance the performance of own units. This behavior could be further encouraged by the fact that high risk-taking franchisees feel less threatened by the risk that their deviance may be uncovered. Proactiveness, similarly, may increase opportunistic tendencies, as this entrepreneurial characteristic is related to searching for opportunities to transform and develop one's own business (Kickul and Gundry, 2002). The interest of the entire system may not necessarily be at the forefront of business activity considerations of franchisees that are highly proactive.

On this basis, individuals who possess high levels of innovativeness, risk-taking, and proactiveness may be successful entrepreneurs, but may simultaneously be less suited for franchise system environments. In particular, the bilateral dependency on which such hybrid 
forms of governance are built (David and Han 2004; Williamson 1991) is in opposition to the very nature of these entrepreneurial characteristics. Therefore, we propose that such individuals are more likely to cope with internal conflicts and therefore pursue their own personal objectives in an opportunistic manner, which can negatively impact the overall success of the system (Cochet, Dormann, and Ehrmann 2008; Mitsuhashi, Shane, and Sine 2008; Sorenson and Sorensen 2001; Yin and Zajac 2004).

Thus, from a franchisor perspective, a dilemma evolves in which the trade-off between potential benefits and hazards of franchisees' entrepreneurial characteristics needs to be considered. Given the managerial importance of these considerations, as they concern ex-ante selection as well as ex-post management practices, it is important to assess empirically the link between individual franchisees' entrepreneurial characteristics and their levels of opportunism. Based on the above discussed literature, we hypothesize:

Hypothesis 1a (H1a): Franchisees' levels of innovativeness are positively related to levels of opportunism.

Hypothesis $1 \mathrm{~b}(\mathrm{H} 1 \mathrm{~b})$ : Franchisees' levels of proactiveness are positively related to levels of opportunism.

Hypothesis 1c (H1c): Franchisees' levels of risk-taking are positively related to levels of opportunism.

\section{The Moderating Effects of Relational Contracting}

The few studies that have explored the link between franchisees' characteristics and franchise system outcomes have not taken contextual moderators, such as governance form or type of contracting, into account (Jambulingam and Nevin 1999). However, research suggests that the 
link between personal characteristics and behavior is moderated by a person's beliefs as to whether it is easy or difficult to perform an act (Ajzen 1991; Krueger and Carsrud 1993). These perceptions, of whether it is easy or difficult to behave in a particular way, depend on past experiences as well as current obstacles to, or opportunities for, the performance of a behavior.

The above observations provide a parallel to TCE and agency theory which both highlight the need for contracting, as otherwise partners or agents will behave in their own interest (Eisenhardt 1989; Williamson 1975). Applied to the franchise context, we argue that ex-post contracting moderates the link between the above discussed entrepreneurial characteristics of franchisees and their levels of opportunism.

Research in TCE and agency theory has traditionally focused on organizational management through formal contracting. This is because in the presence of opportunism and self-interest organizations have to deal with goal divergence between contracting parties. It is important to note, though, that TCE and agency theory have differing underlying assumptions: TCE assumes bounded rationality, suggesting that organizations possess only limited foresight and cannot protect themselves against all eventualities, whereas agency theory suggests that all contingencies can be specified ex-ante (David and Han 2004; Eisenhardt 1989; Kim and Mahoney 2005; Mitsuhashi, Shane, and Sine 2008).

Understanding the efficiency of contracts and different contracting mechanisms, i.e. the extent to which potential opportunistic behavior can be suppressed, is particularly important in franchise system contexts, due to the nature of franchising as a business model. Features such as a dominant entrepreneurial ideology and geographical dispersion lead to opportunities for franchisees to operate units in a self-interested manner that may damage the system in the long 
run (Birkeland 2002). It is for this reason that formal contracting as a control mechanism has been widely discussed in the franchising literature.

A different stream of the literature has advanced the relational contracting approach (Lado, Dant, and Tekleab 2008; Koza and Dant 2007; Macneil 1980), a form of contracting which is increasingly used in practice (Cochet, Dormann, and Ehrmann 2008). In contrast to TCE and agency theory, relationalism embeds exchange into a social context. Some of the key exchange characteristics between partners in relational contracting involve flexibility, information exchange, and collegiate problem-solving (Heide and John 1992; Kaufmann and Stern 1988).

Proponents of relational contracting suggest that it creates economic value through the development of unwritten shared norms, values, and behaviors that safeguard against conflict (Brown, Dev, and Lee 2000). A further advantage may be that this approach is more flexible than formal contracting and can thus be adjusted for the management of different franchisees that come from a wide range of backgrounds and experiences, and as such have varying aspirations and expectations for their units (Birkeland 2002). Moreover, relational contracting may foster autonomy and thus entrepreneurial initiative. Thus, it might aid in the realization of decentralized decision-making, whereas a formal contracting approach could be perceived as providing too narrow a framework for franchisees.

However, herein may also exactly lie a limitation of relational contracting. Referring back to the franchisee-entrepreneur performance dilemma, we point to evidence which suggests that relational contracting may not be robust across all governance forms. This may be particularly the case in governance forms that are higher in ambiguity than hierarchy, such as franchising (Kashyap, Antia, and Frazier 2012). In such contexts, where the principal needs to clearly establish the functions and responsibilities of the agent, relational contracting may be less likely 
to safeguard against opportunism (Carson, Madhok, and Wu 2006). The reason is that relational contracting further increases ambiguity due to the fact that it gives franchisees more autonomy within a framework of rules that are not explicitly stated, as they would be in formal contracting. Therefore, relational contracting through its ambiguity-enhancing properties may moderate the links between entrepreneurial characteristics and opportunistic behavior. ${ }^{1}$

Autonomy is "the extent to which a party, here a franchisee, is unconstrained to independently make decisions and to take action" (Cochet, Dormann, Ehrmann 2008, p. 52). In contrast to formal contracting, relational contracting relies on a set of unwritten rules (e.g., Lado, Dant and Tekleab 2008). This means that in comparison to formal contracting, under relational contracting there is greater ambiguity, a term which refers to the possibility that various interpretations of a situation, information or role are possible which makes them thus doubtful or uncertain. The reason for this is that with unwritten rules, standards are more open to interpretation, more difficult to be reinforced (Carson, Madhok and Wu, 2006) and give thus more leeway in decision-making, which in turn means greater autonomy. While relational contracting mechanisms, such as information exchange, may be reinforced to ensure franchisee collaboration, these mechanisms are by definition less formalized than those deployed under formal contracting and thus provide greater room for autonomy.

Based on the above it can be argued that the link between ambiguity and opportunism has been relatively well established. However, while it has been suggested that relational contracting cannot perfectly enforce cooperative behavior and may thus only provide a partial safeguard to agency costs ex-post (such as costs incurred through opportunistic behavior) (e.g., Jap and

1 It is worth noting that it is beyond the scope of this paper to assess in more detail the mediating role of ambiguity; here, we are concerned with the moderating effect of relational contracting. However, future research should investigate the role of ambiguity to gain further insights into the mechanisms of how relational contracting impacts on the entrepreneurial characteristics-opportunism link. 
Ganesan 2000), as sanctioning is more difficult, if not impossible, only very few studies have in fact investigated to what extent the level of relational contracting may moderate the link between franchisee characteristics (here entrepreneurial characteristics) and franchisee behavior (here opportunistic behavior). It is for this reason that our study focuses on the constructs relational contracting, franchisee characteristics and opportunism. This is particularly important as franchisees, who possess high levels of entrepreneurial motivations, might more actively engage in opportunistic behaviors under stronger relational contracting, as it is difficult for the franchisor to observe, control or sanction such behaviors. Especially, we argue that innovativeness, proactiveness, and risk-taking help to explain franchisees' opportunistic behaviors in case of highly relational governance regimes.

If a franchisee possesses high levels of these three characteristics, they might show a higher probability of engaging in self-interest seeking behaviors which - from the perspective of the franchise system as a whole - are not beneficial, if they are given the opportunity to do so without being observed or sanctioned. On the other hand, franchisees with lower levels of the three entrepreneurial characteristics will possibly be less inclined to opportunistically exploit their freedom. Therefore, we suggest that relational contracting strengthens the opportunismenhancing effects of innovativeness, proactiveness, and risk-taking. Hence:

Hypothesis 2a (H2a): Relational contracting moderates the link between franchisees' innovativeness and opportunism in that it strengthens the positive link between the two constructs.

Hypothesis $2 b(\mathrm{H} 2 \mathrm{~b})$ : Relational contracting moderates the link between franchisees' proactiveness and opportunism in that it strengthens the positive link between the two constructs. 
Hypothesis 2c (H2c): Relational contracting moderates the link between franchisees' risk-taking and opportunism in that it strengthens the positive link between the two constructs.

\section{Conceptual Model}

In summary, the arguments advanced above leading to H1a-c suggest that opportunism (OPP) is increased at the individual franchisee-level (level 1) by three entrepreneurial characteristics. More precisely, we assume that innovativeness (INNO), proactiveness (PRO), and business risktaking $(R I S K)$ are positively related to opportunism. In addition to the three entrepreneurial characteristics, we control for the effect of the time a franchisee has been with the system ( $\left.F R \_A G E\right)$, as it has been suggested that over time more agency conflicts may evolve in a relationship (Cochet, Dormann, and Ehrmann 2008).

Turning to system level effects (level 2), and in line with H2a-c, we assume moderating effects on the franchise system-level (level 2) such that relational contracting $(R E C)$ strengthens the opportunism-enhancing impact of the three entrepreneurial characteristics - innovativeness, proactiveness, and business risk-taking. In addition to investigating the moderating impact of relational contracting as our key construct of interest and in order to avoid model misspecification, we control for the age of the franchise system (AGE_SYS) and the number of franchisees $\left(N O \_F R\right)$. The rational is that franchise system age and the number of franchisees are proxies for franchisor experience which could have an impact on the average opportunism level in a given system (Dant and Gundlach 1999; Lilis, Narayana, and Gilman 1976). We also include average success of the system (SUCC), as there is evidence that performance plays a predominant role in determining partner opportunism (Deeds and Hill 1998). 
A simplified conceptual model is illustrated in Figure 1.

Figure 1 about here

As we have matched data, namely franchisee level data and franchise system level data, whereby the franchisee data is nested in the franchise system data, we use hierarchical linear modeling (HLM) for the analysis (Hox 1995; Muthen and Satorra 1995; Raudenbush and Bryk 2002; Snijders and Bosker 1999). HLM is well suited for our research objectives as it allows for a simultaneous investigation of level 1 drivers of opportunism and level 2 moderators in a single model. The final model looks as follows:

Level 1 opportunism-model

(1) $O P P=\beta_{0}+\beta_{1}(I N N O)+\beta_{2}(R I S K)+\beta_{3}(P R O)+r$

Level 2 opportunism-model

Intercept effects

2) $\beta_{0}=\gamma_{00}+\gamma_{01}\left(A G E_{-} S Y S\right)+\gamma_{02}\left(N O_{-} F R\right)-\gamma_{03}(S U C C)+u_{0}$

Slope effects

3) $\beta_{1}=\gamma_{10}+\gamma_{11}(R E C)+u_{1}$

4) $\beta_{2}=\gamma_{20}+\gamma_{21}(R E C)+u_{2}$

5) $\beta_{3}=\gamma_{30}+\gamma_{31}(R E C)+u_{3}$

\section{Method}

\section{Data Collection}

We first compiled a list of 153 franchise systems operating in Germany. This list only contains systems that are organized in the German Franchise Association and that have had at 
least five franchisees for the last two years. We asked the franchisors for their support by providing a list of their franchisees for us to survey. 22 systems offered their support. The final sampling list contains a total of 2,530 franchisees across the 22 systems. It is also worth mentioning that all cases from the franchisee data can be matched to a particular franchise system, enabling a multi-level analysis.

Data for our study were collected through standardized questionnaires. 321 usable questionnaires were returned which equates a response rate of 12.3 percent. With regard to system size, the majority (64 percent) of systems consist of a maximum of 100 franchisees, 36 percent are between 101 and 500 franchisees (mean=115) with a system-wide turnover of 187 Mio Euros $(S . D .=57 \mathrm{Mio})$. On average, franchisees belong to systems that have been on the market for 25 years $($ S.D. $=9.06)$. Moreover, the majority of franchisees $(67.3$ percent $)$ are from the service and retail sector and can be considered small business operations. Table 1 provides a detailed breakdown of the sample ${ }^{2}$.

Table1 about here

Apart from the primary data collected from the franchisees, we also gathered secondary data on the franchise systems, using the franchise systems' websites, objective information provided by the franchisor, various franchise handbooks, annual reports, reports from the national franchise associations, and other publically available sources.

2 While not claiming representativeness, our sample seems to be a good representation of the overall franchise market in Germany: 52.3 percent services industries (41.2 percent in Germany); 26.8 percent retailing (22.5 percent); 7.5 percent hotel and fast-food industries (13.5 percent); 7.8 percent handcraft and construction services ( 7.3 percent); 0 percent fitness and health industries (5.4 percent); 5.6 percent tourism industries (4.1 percent); and 0 percent others industries (6 percent). 


\section{Measures}

Level 1 measures. In the survey, we measure each franchisee's entrepreneurial characteristics (innovativeness $(I N N O)$, proactiveness $(P R O)$, and business risk-taking (RISK)) (Covin and Slevin 1986, 1989; Jambulingam and Nevin 1999; Lumpkin, Cogliser, and Schneider 2009; Miller 1983). The analysis suggests that all measures are valid and reliable. Particularly, discriminant validity is given since correlations are generally rather low and none of the squared correlations between pairs of constructs exceed the Average Variance Extracted $(A V E)$ of either construct (Fornell and Larcker 1981). We also measure opportunism (OPP; $C R=.901 ; A V E=$ .787) with seven items suggested by Jambulingam and Nevin (1999) ${ }^{3}$.

We also assess common method bias as level-1 items are from the same source. Using the procedure suggested by Podsakoff et al. (2003), we note that common method variance does not seem to be a severe issue in our data ${ }^{4}$.

We calculate scale means of the three independent variables as well as the dependent variable for our HLM analysis. Apart from these level 1 measures, we also assess the years a franchisee has been a part of the system $\left(A G E \_F R\right)$.

Level 2 measures. On the franchise system level, we use objective company data to assess the age of the franchise systems $\left(A G E \_S Y S\right)$ and the number of franchisees in the system $\left(N O \_F R\right)$ as a measure for system size. Moreover, we use the relational contracting measures from the franchisee survey to aggregate them to the system level (as suggested by Kozlowski and Klein, 2000). It is deemed suitable to aggregate level 1 data to level 2 as the intraclass correlation ICC (1) is larger than .2, the $I C C$ (2) is larger than .7, and the mean $\mathrm{R}_{\mathrm{wg}(\mathrm{j})}$ is larger than .8 (Bliese

3 To further assess the quality of these measures, we run EFA and CFA and find no cross-loadings, but a good overall fit of the measurement model (chi-squared $/ D F=1.976 ; A G F I=.932 ; T L I=.913 ;$ RMSEA $=.042$ ).

4 Details of these analyses are available upon request. 
2000). We thereby calculate a system-wide measure of the degree of relational contracting (REC; $C R=.897 ; A V E=721$ ), which is assessed using the key dimensions flexibility, information exchange, and collegiate problem-solving (Brown, Dev, and Lee 2000; Heide and John 1992; Jambulingam and Nevin 1999; Kaufmann and Stern 1988). Moreover, we measure perceptions of success of the franchise system (SUCC; $C R=901 ; A V E=.698)$. Discriminant validity is not an issue in our level 2 data as the variables are not significantly correlated. As before, we create scale means for all level 2 variables.

Co-variables. At level 1, we include the age of the franchise system and the number of franchisees as measures of franchisor experience. Literature finds support for the notion that more experienced franchisors should be more advanced in terms of franchisee selection, incentive design and monitoring (Stump and Heide 1996). We also include system performance corresponding to the study of Deeds and Hill (1998), who found that alliance performance plays a predominant role in determining partner opportunism. The theoretical rationale for this effect is that underperforming partnerships usually go along with disappointment and friction in the relationship. Thereby, blame for failure is regularly allocated to the franchisor. Due to the high level of dependency of the franchisee, the probability of behaving opportunistically increases.

Table 2 provides key psychometric properties of the level 1 and level 2 measures. For a complete overview of all the items used in the survey, please refer to the Appendix.

Table 2 about here 


\section{Analysis Overview}

As suggested by Raudenbush and Bryk (2002), we employ hierarchical linear modeling (HLM) to analyze our data, as we have two levels of data, namely franchisee level data and franchise system level data, whereby the franchisee data is nested in the franchise system data. Hence, ordinary regression analysis would not be appropriate since such data violates the assumption of independence of observations (error-term correlation), a key premise of regression analysis (Hox 1995; Raudenbush et al. 2004; Snijders and Bosker 1999). Clearly, our franchisee data points are not independent, but nested in higher level groups, in our case the franchise system an individual franchisee belongs to.

Along suggestions by Raudenbush and Bryk (2002) as well as Muthen and Satorra (1995), we first of all assess if there is sufficient variation between the 22 franchise systems with respect to opportunism, our dependent variable. In order to do so, we calculate the design effect $(D E F F)$ as an average class size adjusted intra-class correlation (ICC) as follows:

$$
D E F F=1+(c-1) \times\left(\sigma_{B}^{2} /\left(\sigma_{B}^{2}+\sigma_{W}^{2}\right)\right)
$$

with $c$ being the average class size, $\sigma_{B}^{2}$ the between-class correlation, and $\sigma_{W}^{2}$ the within-class correlation. Muthen and Satorra (1995) suggest that whenever DEFF is larger than 2, there is sufficient reason to assume a severe violation of the assumption of independent observations across all classes, and propose that in such a case multilevel analysis should be employed. Our results show that the design effect for opportunism is $D E F F=8.44$. Therefore, HLM is an appropriate technique to analyze our data. 


\section{Results}

Based on our conceptual model, we estimate a random intercept/random slope model. Table 3 provides estimations of the unstandardized regression coefficients for all level 1 and level 2 effects.

Table3 about here

We note that the three independent variables are very weakly correlated (Table 2) and when including all in a regression analysis, variance inflation factors (VIFs) are between 1.009 and 1.308, sufficiently below the threshold suggested in the literature (Hair et al. 2006). Hence, multicollinearity is not an issue in our data. The results of our HLM model show that the independent variables, except innovativeness, significantly predict opportunism. More precisely, we find that a one-unit change in risk-taking leads to an increase in opportunism of .676 points (on the five-point opportunism scale); similarly, a one-unit increase in proactiveness results in a .180 point increase in opportunism.

We also note that the co-variable franchisee age is negatively related to opportunism such that a one-unit increase in age leads to a $.591 * 10^{-3}$ decrease in opportunism.

Turning to the level 2 intercept effects of the three co-variables, we find that age and success of the franchise do not seem to be related to the average opportunism level in the system. We further note that the size of a franchise system (measured by the number of franchisees) is significantly, systematically, and positively related to average opportunism levels in a particular franchise system, possibly suggesting that larger systems are more prone to opportunistic behavior of their franchisees. 
As for the key level 2 slope effects, we find some support for the assumption that relational contracting increases the positive (opportunism increasing) effects of innovativeness, proactiveness, and business risk-taking on opportunism. However, only the moderating effect on the link between business risk-taking and opportunism is significant at the .05-level, while the innovativeness-opportunism link is only significant at the $.1-$ level $^{5}$. The proactivenessopportunism link is moderated in the expected direction, yet, the effect is statistically nonsignificant $(t=.926 ; p>.1)$. Taken together, these findings provide only partial support for hypothesis $2^{6}$.

\section{Discussion and Implications}

\section{Contribution to Theory}

Research grounded in TCE focuses on the efficiency of governance form and contracting to safeguard against opportunism (e.g., Mitsuhashi, Shane, and Sine 2008; Sorenson and Sorensen 2001). Based on agency theoretical considerations (Eisenhardt 1989), we argue that also individual agent motivation needs to be taken into account in order to explain variance in opportunism. This research contributes to existing franchising research first of all by showing that franchisees' entrepreneurial characteristics impact partially on opportunism (Castrogiovanni, Combs, and Justis 2006). This carries implications for the assessment and reduction of transaction costs ex-ante, for example through social mechanisms such as selective franchisee recruitment (Birkeland 2002).

5 We are aware that the normal cut-off value for significance of effects is .05. However, considering the sample size at level $2(\mathrm{n}=22)$ and the $\mathrm{t}$-value of 1.882 , we argue that reporting the effect as non-significant might be unadvisable.

6 The inclusion of an industry-dummy as a co-variable yielded a non-significant result for the dummy. 
Specifically, looking at the results of our Hypotheses H1b and H1c, we note that proactiveness and risk-taking are important antecedents of franchisee opportunism (Jambulingam and Nevin 1999). The dimension franchisee innovativeness, however, did not show the positive relationship assumed in Hypothesis H1a. Therefore, it needs to be said that the relationship between innovativeness and opportunism may be less straightforward compared to the other two entrepreneurial characteristics under investigation here. Given that franchise systems vary to a large degree in terms of innovation management practices, the existence and direction of the relationship between innovativeness and opportunism might depend on the experience franchisees have made when trying to market innovative ideas at the system level. Franchisors who keep responsibilities for innovation development in their own realm of activities might in fact encounter problems such as intra-system inertia (Kaufmann and Eroglu 1999), less cooperation or an increased probability of opportunism with highly innovative franchisees. In franchise systems in which franchisees are actively encouraged to participate in innovation processes, however, the assumed relationship might not necessarily exist. Given that innovation activities are traditionally seen as the duty of the franchisor (Falbe, Dandridge and Kumar 1999), there is a point to be made here that the potential of innovative franchisees may be realized without the negative aspects of an increased level of opportunism.

Empirically, the reason for the non-significant impact might be the fact that innovativeness has a rather low standard deviation. This suggests that innovativeness does not differ a great deal among franchisees. While this does not imply that innovativeness is not an important predictor of opportunism, it suggests that variation in innovativeness is unlikely to explain the variation in the opportunism construct. 
Taken together, the results of hypotheses H1a-c show that it is useful to look at the three entrepreneurial characteristics separately, instead of aggregating them to one higher-order construct, entrepreneurial orientation, when investigating outcomes such as opportunism (Kreiser, Marino, and Weaver 2002; Lumpkin and Dess 1996). Thereby, our findings complement the results of a meta-analysis investigating the relationship between personality characteristics and entrepreneurial status (Zhao and Seibert 2006), which reveals that one of the Big Five personality traits, agreeableness, is negatively related to entrepreneurial status. Thus, according to the definition of agreeableness, entrepreneurs seem to be more strongly determined by self-interest, while being less altruistic, forgiving or gullible (Zhao and Seibert 2006). However, our results indicate that this may only hold for the entrepreneurial characteristics proactiveness and risk-taking, but not for innovativeness.

In the case of franchising as a hybrid governance form, and using franchisees' entrepreneurial characteristics and relational contracting as examples, we demonstrate how elements of ex-post contracting moderate the link between individual agent motivation and important outcomes. More precisely, our data show that relational contracting strengthens the link between risk-taking and opportunism, and (to a lesser degree) between innovativeness and opportunism. Put differently, we find that the opportunism-increasing effect of risk-taking is further increased by relational contracting, rendering this form of governance in a franchise context questionable. In addition, while innovativeness has not been identified as a direct antecedent of opportunism, it is important to be aware of its opportunism increasing effects when following a relational contracting approach. It should be mentioned that this finding does not suggest that the use of relational contracting is unsuitable for safeguarding against opportunism; however, it suggests 
that there exists at least one boundary condition for relational contracting to protect against opportunistic behavior.

This result contributes to the understanding of a key dilemma in franchising: While there is evidence that higher levels of autonomy - which can be fostered through relational contracting are important to leverage the entrepreneurial capacities of franchisees (Kaufman and Eroglu 1999; Schul, Little, and Pride 1985; Strutton, Pelton, and Lumpkin 1995), we demonstrate that at the same time this form of contracting encourages opportunistic behavior. The potential reason for this observation is that relational contracting - compared to hierarchical forms of governance - increases the already existing ambiguity in hybrid governance forms, such as franchise systems. The consequence is that it is not only more difficult to evaluate the actions of franchisees in the first place, but also to correctly interpret franchisees' behaviors as compliant or opportunistic (Carson, Madhok, and Wu 2006). Therefore, the boundaries for the judgment of and sanctioning against opportunism may become more blurred. We have to note, however, that this is our interpretation of the effect and we do not have the necessary data to formally test the mediating role of ambiguity in the moderating effect of relational contracting. Further research should possibly consider doing this as a fruitful avenue for advancing our understanding of the functioning of relational contracting.

As expected, franchisee age reduces opportunism, possibly through the fact that franchisee trust increases over time (after an initial drop; see: Blut et al. 2011), which likely reduces opportunism. Moreover, it can be argued that the longer a franchisee is part of a franchise system, the more the norms affect their behavior - thus leading to the inverse relationship between franchisee age and opportunism.

\section{Managerial Implications}


The results of our study have several managerial implications. Given that proactiveness and risk-taking are at least partially linked to opportunism, franchisors should more fully consider how to select potential franchisees and assess future transaction costs ex-ante. For example, it is possible that individuals with higher levels of proactiveness and risk-taking may not necessarily drive franchise system performance. Instead, they may cause more ex-post transaction costs due to opportunistic behavior.

Looking at the relative magnitude of the effects, risk-taking $(\mathrm{H} 1 \mathrm{c})$ can be identified as the variable that is - by far - most strongly related to opportunism. Thus, it might be useful for franchisors to incorporate assessments of risk-taking into their selection policies. However, innovativeness (H1a) does not seem to be a "warning sign" of future opportunistic behavior under all circumstances. Given that ideas generated by individual franchisees are an increasingly important source to secure and develop a franchise system's business model (in the case of McDonald's, the invention of the BigMac and McCafé provide famous examples of innovations that originated from franchisee initiatives), there is, in general, less danger in offering franchise contracts to candidates who have a proven track record of innovative ideas. Selecting franchisees on the basis of their innovative capabilities, thus, might be generally useful, since such candidates might probably engage in advancing the franchise system as a whole without primarily seeking their self-interest and exhibiting free-riding tendencies. In franchise systems that follow a highly relational contracting approach, however, innovativeness may foster opportunism. Therefore, franchisors who intend to capitalize on their franchisee's innovation capabilities should take care of having implemented suitable (formalized) follow-up processes to effectively handle franchisee initiatives at the franchise system level. In addition, if innovative franchisees are prevented from implementing their ideas in their own outlets by their franchisor, 
this may similarly result in negative consequences such as reactance, less cooperation and opportunism.

Considering the above, a combination of methods, including the assessment of objective information, such as prior business experience, as well as a candidate's personality and motivations, including risk-taking and proactiveness (Jambulingam and Nevin 1999), may enable franchisors to identify the most suited future franchisees. For example, one characteristic that franchisors may be looking for is franchisees' willingness to cooperate. This in combination with the entrepreneurial capacity of innovativeness could be a good foundation in order to implement a system strategy properly, augmented through the ideas and initiatives of the franchisee. Looking at the results related to $\mathrm{H} 2 \mathrm{c}$, it is suggested that in the case of a highly relational contract regime, franchisors should be especially aware of the danger of allowing franchisees with a high propensity to risk-taking to enter their system.

It is also possible that individuals with stronger entrepreneurial motivations are more likely to exit the system sooner, as they become frustrated and dissatisfied with the boundaries set within franchise systems in general (Ping 1993). Evidence for this could be our finding that there is a negative link between the number of years of belonging to a franchise system and levels of opportunism. It is quite possible that franchisees who have, for example, a stronger entrepreneurial motivation and/or more substantial business experience will want to leverage their capacities more fully and in their own terms. For this reason they may strive for more autonomy and, if this is not being granted within the system, may decide to open their own venture.

The key managerial implication for franchisors is to be aware of a "dark side" of entrepreneurial motivation: opportunistic behavior. It seems that franchisors cannot have one 
without the other and thus have to find a balance between the two that best suits their system. It is necessary to understand where the optimal point lies that gives entrepreneurial and successful franchisees enough flexibility to exploit their capacities, and thereby keep them satisfied and in the system, whilst at the same time not running into the danger of creating opportunities for selfinterested actions that may damage the system.

The identification of how this balance can be achieved is beyond the scope of our paper. However, there is one suggestion we would like to be considered: Related to the above discussion of franchisors selecting franchisees is the notion of franchisees' self-selection. If the franchise system establishes through external communications, such as recruitment ads and promotional material, a realistic picture of what is expected of franchisees, it is more likely that candidates with a better fit with the system apply as potential franchisees. As a result, it might be easier for management to identify the right balance between flexibility and control, as the gap between franchisees' and franchisors' expectations in relation to behavioral norms may be smaller (Bretz and Judge 1998).

There is also an alternative explanation for the negative link between the length of franchisees belonging to a system and levels of opportunism: With increased years of membership any contractual arrangements, formal or relational, may become better defined which decreases the propensity to behave opportunistically. Due to reasons of bounded rationality, franchisors cannot anticipate all problems that may arise throughout a partnership with a franchisee. Therefore, initial formal contracts may be suboptimal at the start. However, with the evolution of the system, franchisors' increasing experience and knowledge of specific franchisees, new contracts for franchisees entering the system in the future may become more efficient over time (Cochet and Garg 2008). At the same time, in order to safeguard against opportunism and to ensure 
performance over time of existing franchisees, franchisors can complement the content of contracts by specifying performance terms and control mechanisms post-hoc (Arruñada, Garicano and Vázquez 2001). Thus, formalization, which is regarded as a cost of contracting, may in fact be beneficial within a franchise system as it serves as a frame of reference to identify opportunistic behavior (Combs and Ketchen 1999). Alongside formalization also dimensions of relational contracting can develop over time, which may lead to stronger social barriers to opportunism. In cases where relational contracting does not establish appropriate safeguards, franchisors can still retain the right to complete existing formal contracts with additional terms.

These arguments lend support for the notion that through learning and experience with specific franchisees, franchisors become better at efficient contracting, which in turn should positively impact on a system's success. The managerial implication for franchisors is that it might be desirable to ensure that franchisees stay in the system for longer. Again, in order to achieve this, franchisors need to be aware of the trade-off they have to make between granting enough autonomy to keep franchisees, and setting enough boundaries in order to prevent opportunism. In order to achieve this successfully, franchisors may have to consider the experience and characteristics of individual franchisees as well as their position in the franchisee-lifecycle (Blut et al. 2011).

Therefore, while it sounds plausible that franchisees need to be treated the same throughout the system in order to avoid internal quarrels, there is an argument to be made whether the management of franchisees can be really standardized. Given that these individuals have made over the years different experiences in the franchise system, have very different backgrounds, capacities, and aspirations, it is possible that an idiosyncratic approach to franchisee management might be more efficient (Birkeland 2002). This can also be achieved by the franchisors' right to 
complete existing individual contracts after franchisees have entered the system (Arruñada, Garicano and Vázquez 2001).

An idiosyncratic approach would not only consider contracting methods, either formal or informal, but also include other practices such as the identification of individual training and development needs and opportunities. For example, highly driven and successful individuals could be more quickly given the option to develop entire regions through the ownership of multiple units. Through such initiatives, a stronger sense of achievement may be instilled, which in turn could lead to higher levels of satisfaction and longer loyalty to the system (Ping 1993).

\section{Conclusion and Directions for Future Research}

To conclude, we suggest that, in general, managers should take into account that relational contracting might not be efficient in safeguarding against all risks of opportunism, in particular as the level of franchisees' entrepreneurial motivation impacts on opportunistic tendencies. It is for these reasons that franchisors need to be aware of the dilemma they are facing in order to make an efficient ex-ante selection, as well as ex-post contracting decisions: Entrepreneurially minded franchisees who might be better at exploiting market opportunities for their units may at the same time behave more opportunistically, if given the chance. However, if they perceive the contractual framework as being too narrow, they may exit the system faster in order to start their own venture. As we observed a negative link between a franchisees' time in the system and the tendency to act opportunistically, it seems a worthwhile pursuit to keep franchisees satisfied and in the system.

Following this thought, there is great merit to explore further whether initial transaction costs caused by opportunism of entrepreneurially oriented franchisees outweigh the later gains through 
gradually more efficient contracting and revenue streams through franchisees' entrepreneurial motivation.

Finally, we would like to point out that we only focused on the extent to which relational contracting may or may not safeguard against negative effects stemming from entrepreneurial characteristics. In order to gain a better insight into the advantages and disadvantages of different types of contracting in hybrid governance forms, studies should compare the effects of formal and relational contracting (Carson, Madhok, and Wu 2006). It may be particularly interesting to analyze how these two types of contracts develop and define the relationship between franchisors and franchisees over time (Cochet and Garg 2008). As in organizational reality the two types of contracting may complement each other (Poppo and Zenger 2002), there is merit to investigate in more depth how the two are interrelated and impact on franchisors' transaction costs.

In conclusion and despite the limitations of our study, our results point to an important dilemma franchisors need to be aware of: Entrepreneurially minded franchisees who might be better at exploiting market opportunities may also behave more opportunistically, if given the chance through a more relational contracting regime. At the same time, if they perceive the contractual framework as being too rigid, they may be less able to leverage their capabilities, become dissatisfied and exit the system. That is arguably the key challenge in franchising. 


\section{References}

Ajzen, I. (1991). “The Theory of Planned Behaviour," Organizational Behavior and Human Decision Processes, 50(2), 179-211.

Arruñada, B., Garicano, L., and Vázquez, L. (2001). "Contractual Allocation of Decision Rights and Incentives: The Case of Automobile Distribution," Journal of Law, Economics \& Organization, 17(1), 257-284.

Aulakh, P. S., and Gençtürk, E. F. (2007). "Contract Formalization and Governance of ExporterImporter Relationships," Journal of Management Studies, 45(3), 457-479.

Berg, S. V., and Friedman, P. (1980). "Causes and Effects of Joint Venture Activity: Knowledge Acquisition versus Parent Horizontality,” Antitrust Bulletin, 25(1), 143-168.

Birkeland, P. M. (2002). Franchising Dreams: The Lure of Entrepreneurship in America. University of Chicago Press.

Bliese, P. D. (2000). “Within-group Agreement, Non-Independence, and Reliability: Implications for Data Aggregation and Analysis," Multilevel Theory, Research, and Methods in Organizations, Klein K. J. and Kozlowski S. W. J. (Eds), Jossey-Bass: San Francisco, CA, 349-381.

Blut, M., Backhaus, C., Heussler, T., Woisetschlager, D., Evanschitzky, H., and Ahlert, D. (2011). "What to Expect after the Honeymoon: Testing a Lifecycle Theory of Franchise Relationships," Journal of Retailing, 87(3), 306-319.

Bretz, R., and Judge, T. (1998). "Realistic Job Previews: A Test of the Adverse Self-Selection Hypothesis," Journal of Applied Psychology, 83(2), 330-337.

Brown, J. R., Dev, C. S., and Lee, D. (2000). "Managing Marketing Channel Opportunism: The Efficacy of Alternative Governance Mechanisms," Journal of Marketing, 64(April), 51-65. 
Caliendo, M., Fossen, F., and Kritikos, A. (2009). "Risk Attitudes of Nascent Entrepreneurs New Evidence from an Experimentally Validated Survey," Small Business Economics, 32(2), $153-167$.

Carland, J. W., Hoy, F., Boulton, W. R., and Carland, J. A. C. (1984). “Differentiating

Entrepreneurs from Small Business Owners: A Conceptualization," Academy of Management Review, 9(2), 354-359.

Carney, M., and Gedajlovic, E. (1991). "Vertical Integration in Franchise Systems: Agency Theory and Resource Explanations," Strategic Management Journal, 12(8), 607-629.

Carson, S. J., Madhok, A., and Wu, T. (2006). "Uncertainty, Opportunism and Governance: The Effects of Volatility and Ambiguity on Formal and Relational Contracting," Academy of Management Journal, 49(5), 1058-1077.

Castrogiovanni, G. J., Combs, J. G., and Justis, R. T. (2006). "Resource Scarcity and Agency Theory Predictions Concerning the Continued Use of Franchising in Multi-Outlet Networks," Journal of Small Business Management, 44(1), 27-44.

Cochet, O., and Garg, V. (2008). "How do Franchise Contracts Evolve? A Study of Three German SMEs," Journal of Small Business Management, 46(1), 134-151. -, Dormann, J., and Ehrmann, T. (2008). “Capitalizing on Franchisee Autonomy: Relational Forms of Governance as Controls in Idiosyncratic Franchise Dyads," Journal of Small Business Management, 46(1), 50-72.

Combs, J. G., and Ketchen, D. J. (1999). "Can Capital Scarcity Help Agency Theory Explain Franchising? Revisiting the Capital Scarcity Hypothesis," Academy of Management Journal, 42(2), 196-207. 
Covin, J. G., and Slevin D. P. (1986). "The development and testing of an organization-level entrepreneurship scale," in R. Ronstadt, J. A. Hornaday and K. H. Vesper (Eds.), Frontiers of Entrepreneurship Research. Wellesley, MA: Babson College.

and Slevin, D. P. (1988). "The Influence of Organization Structure on the Utility of an Entrepreneurial Top Management Style," Journal of Management Studies, 25(3), 217259.

, and Wales, W. J. (2012). “The Measurement of Entrepreneurial

Orientation," Entrepreneurship Theory and Practice, 36(4), 677-702.

Dant, R. P., and Gundlach, G. T. (1999). "The Challenge of Autonomy and Dependence in Franchised Channels of Distribution," Journal of Business Venturing, 14(1), 35-67.

David, R. J., and Han, S. (2004). “A Systematic Assessment of the Empirical Support for Transaction Cost Economics," Strategic Management Journal, 25(1), 39-58.

Davies, W. L., Manolis, C. Prince, M., and Winsor, R. D. (2011), “A Model of Trust and Compliance in Franchise Relationships,” Journal of Business Venturing, 26 (3), 321-340.

Deeds and Hill 1999, “An Examination of Opportunistic Action Within Research Alliances: Evidence from the Biotechnology Industry”, Journal of Business Venturing, 14(2), 141-163. Delmar, F. (1996). Entrepreneurial Behavior and Business Performance. Stockholm: Stockholm School of Economics. , and Davidsson, P. (2000). "Where Do They Come From? Prevalence and Characteristics of Nascent Entrepreneurs," Entrepreneurship and Regional Development, 12(1), 1-23.

Eisenhardt, K. M. (1989). “Agency Theory: An Assessment and Review,” Academy of Management Review, 14(1), 57-74. 
El Akremi, A., Mignonac, K, and Perrigot, R. (2011). “Opportunistic Behaviors in Franchise Chains: The Role of Cohesion among Franchisees," Strategic Management Journal, 32(9), 930-948.

Eysenck, H. J. (1976). The Measurement of Personality. Baltimore: University Park Press. Fornell, C., and Larcker, D. F. (1981). "Evaluating Structural Equation models with Unobservable Variables and Measurement Error,” Journal of Marketing Research, 18 (February), 39-50.

Frazer, L., and Winzar, H. (2005). "Exits and Expectations: Why Disappointed Franchisees Leave,” Journal of Business Research, 58(11), 1534-1542.

George, B., and Marino, L. (2011). “The Epistemology of Entrepreneurial Orientation: Conceptual Formation, Modeling, and Operationalization," Entrepreneurship Theory \& Practice, 35(5), 989-1024.

George, J. M. and Zhou, J. (2001). "When Openness to Experience and Conscientiousness are Related to Creative Behavior: An Interactional Approach," Journal of Applied Psychology, $86(3), 513-524$.

Gillis, W. E., McEwan, E., Crook, T. R., and Michael, S. C. (2011). “Using Tournaments to Reduce Agency Problems: The Case of Franchising," Entrepreneurship Theory \& Practice, $35(3), 427-447$.

Grünhagen, M., and Mittelstaedt, R. A. (2005). "Entrepreneurs or Investors: Do Multi-Unit Franchisees Have Different Philosophical Orientations," Journal of Small Business Management, 43(3), 207-225.

Hair, J., Black, W. C., Babin, B., Anderson, R. E., and Tatham, L. (2006). Multivariate Data Analysis. Englewood Cliffs, NJ: Prentice Hall. 
Heide, J.B., and John, G. (1992). “Do Norms Matter in Marketing Relationships?” Journal of Marketing, 56(2), 32-44.

Hoetker, G., and Mellewigt, T. (2009). "Choice and Performance of Governance Mechanisms: Matching Alliance Governance to Asset Type," Strategic Management Journal, 30(10), $1025-1044$.

Hox, J. J. (1995). Applied Multilevel Analysis. Amsterdam: TT-Publikaties.

Hunt, S. D. (1977). “Franchising: Promises, Problems, Prospects,” Journal of Retailing, 53(3), $71-84$.

Jambulingam, T., and Nevin, J. R. (1999). "Influence of Franchisee Selection Criteria on Outcomes Desired by the Franchisor," Journal of Business Venturing, 14(4), 363-395.

Jap, S. D. and Ganesan, S. (2000). Control Mechanisms and the Relationship Life Cycle: Implications for Safeguarding Specific Investments and Developing Commitment, Journal of Marketing Research, 37(2), 227-245.

Kashyap, V., Antia, K D., and Frazier, G. L. (2012). “Contracts, Extracontractual Incentives, and Ex-Post Behavior in Franchise Channel Relationships", Journal of Marketing Research, 49(2), 260-276.

Kaufman, P. J., and Eroglu, S. (1999). "Standardization and Adaptation in Business Format Franchising," Journal of Business Venturing, 14(1), 69-85. , and Dant, R. P. (1999). "Franchising and the Domain of Entrepreneurship Research," Journal of Business Venturing, 14(1), 69-85. , and Rangan, V. K. (1990). “A Model for Managing System Conflict During Franchise Expansion," Journal of Retailing, 66(2), 155-173. 
----------------, and Stern, L. W. (1988). 'Relational Exchange Norms, Perceptions of Unfairness, and Retained Hostility in Commercial Litigation," Journal of Conflict Resolution, 32(2), 534552.

Ketchen, D. J., Short, J. C., and Combs, J. G. (2011). “Is Franchising Entrepreneurship? Yes, No, and Maybe So," Entrepreneurship Theory \& Practice, 35(3), 583-593.

Kidwell, R., and Nygaard, A. (2011). “A Strategic Deviance Perspective on the Franchise Form of Organizing," Entrepreneurship Theory \& Practice, 35(3), 467-482.

Kickul, J., and Gundry, L. (2002). "Prospecting for Strategic Advantage: The Proactive Entrepreneurial Personality and Small Firm Innovation”, Journal of Small Business Management, 40(2), 85-97.

Kim, J., and Mahoney, J. (2005). "Property Rights Theory, Transaction Costs Theory, and Agency Theory: An Organizational Economics Approach to Strategic Management,” Managerial \& Decision Economics, 26(4), 223-242.

Kochhar, R. (1996). "Explaining Firm Capital Structure: The Role of Agency Theory vs. Transaction Cost Economics,” Strategic Management Journal, 17(9), 713-728.

Korunka, C., Frank, H., Lueger, M., and Mugler, J. (2003). “The Entrepreneurial Personality in the Context of Resources, Environment, and the Startup Process - A Configurational Approach," Entrepreneurship Theory \& Practice, 28(1), 23-42.

Koza, K. L., and Dant, R. P. (2007). "Effects of Relationship Climate, Control Mechanism, and Communications on Conflict Resolution Behavior and Performance Outcomes," Journal of Retailing, 83(3), 279-296.

Kozlowski, S. W., and Klein, K. J. (2000). “A Multilevel Approach to Theory and Research in Organizations," in K. Klein and S. Kozlowski (Eds.), Multilevel Theory, Research, and 
Methods in Organizations: Foundations, Extensions and New Directions. San Francisco: Jossey-Bass.

Kreiser, P.M., Marino, L., and K.M. Weaver (2002). "Assessing the Psychometric Properties of the Entrepreneurial Orientation Scale: A Multi-Country Analysis," Entrepreneurship Theory \& Practice, 26(4), 71-94.

Krueger, N. F. and Carsrud, A. L. (1993). "Entrepreneurial Intentions: Applying the Theory of Planned Behavior," Entrepreneurship \& Regional Development, 5, 315-330.

Lado, A. A., Dant, R., and Tekleab, A. G. (2008). “Trust-Opportunism Paradox, Relationalism, and Performance in Interfirm Relationships: Evidence from the Retail Industry," Strategic Management Journal, 29(4), 401-423.

Li, Z. G., and Dant, R. P. (1997). “An Exploratory Study of Exclusive Dealing in Channel Relationships," Journal of the Academy of Marketing Science, 25(3), 201-213.

Li, Y. H., Huang, J. W., and Tsai, M. 2009. "Entrepreneurial Orientation and Firm Performance: The Role of Knowledge Creation Process," Industrial Marketing Management, 38 (4), 440449.

Lilis, C. M., Narayana, C. L., and Gilman, J. L. (1976). "Competitive Advantage Variation over the Life Cycle of a Franchise," Journal of Marketing, 40(4), 77-80.

-------------, Cogliser, C., and Schneider, D. R. (2008).’Understanding and Measuring Autonomy: An Entrepreneurial Orientation Perspective," Entrepreneurship Theory \& Practice, 33(1), 47-69.

Lumpkin, G. T., and Dess, G. G. (1996). "Clarifying the Entrepreneurial Orientation Construct and Linking It to Performance," Academy of Management Review, 21 (1), 135-172. 
Orientation to Firm Performance: The Moderating Role of Environment and Industry Life Cycle," Journal of Business Venturing, 16 (5), 429-451.

Lusch, R. F., and Brown, J. R. (1996). "Interdependency, Contracting, and Relational Behavior in Marketing Channels", Journal of Marketing, 60 (4), 19-38.

Luo, Y. (2002). “Contract, Cooperation and Performance in International Joint Ventures,” Strategic Management Journal, 23, 903-919.

Macneil, I. R. (1980), The New Social Contract: An Inquiry into Modern Contractual Relations, New Haven, Yale University Press.

Michael, S. C., and Combs, J. G. (2008). “Entrepreneurial Failure: The Case of Franchisees,” Journal of Small Business Management, 46(1), 73-90.

Miller, D. (1983). “The Correlates of Entrepreneurship in Three Types of Firms," Management Science, 29(7), 770-791.

Mitsuhashi, H., Shane, S., and Sine, W. D. (2008). “Organization Governance Form in Franchising: Efficient Contracting or Organizational Momentum?” Strategic Management Journal, 29(10), 1127-1136.

Morgan, R. M. and Hunt, S. D. (1994). “The Commitment-Trust Theory of Relationship Marketing," Journal of Marketing, 58 (3), 20-38.

Morris, M. H. and Sexton, D. L. (1996). “The Concept of Entrepreneurial Intensity: Implications for Company Performance, Journal of Business Research, 36(1), 5-13.

Muthen, B. O., and Satorra, A. (1995). “Complex Sample Data in Structural Equation Modelling," Sociological Methodology, 25, 267-316. 
Nair, S. K., Tikoo, S., and Liu, S. (2009). "Valuing Exclusivity from Encroachment in Franchising," Journal of Retailing, 85(2), 206-210.

Norton, S. W. (1988). “An Empirical Look at Franchising as an Organizational Form,” Journal of Business, 61(2), 197-218.

Palmatier, R. W., Dant, R. P., and Grewal, D. (2007). “A Comparative Longitudinal Analysis of Theoretical Perspectives of Interorganizational Relationship Performance," Journal of Marketing, 71, 172-194.

Ping, R. A. (1993). “The Effects of Satisfaction and Structural Constraints on Retailer Exiting, Voice, Loyalty, Opportunism, and Neglect," Journal of Retailing, 69(3), 320-352.

Podsakoff, P. M., MacKenzie, S. B. Lee, J. Y., and Podsakoff, N. P. (2003). "Common Method Biases in Behavioral Research: A Critical Review of the Literature and Recommended Remedies," Journal of Applied Psychology, 88 (5), 879-903.

Poppo, L., and Zenger, T. (2002). "Do Formal Contracts and Relational Governance Function as Substitutes or Complements?” Strategic Management Journal, 23(8), 707-725.

Powell, W. W. (1990). “Neither Market nor Hierarchy: Network Forms of Organization”. In B. M. Staw, and L. L. Cummings (Eds.), Research in Organizational Behavior. Greenwich, CT: JAI Press.

Price, S. (1997). The Franchise Paradox - New Directions, Different Strategies. London, UK: Cassell.

Raudenbush, S. W., and Bryk, A. S. (2002). Hierarchical Linear Models: Applications and Data Analysis Methods. Newbury Park, CA: Sage. 
---------------, ----------------, Cheong, Y. F., Congdon, R.. and du Toit, M. (2004). HLM 6 :

Hierarchical Linear and Nonlinear Modeling. Lincolnwood, IL: Scientific Software International.

Runco, M. (2004). “Creativity,” Annual Review of Psychology, 55(1), 657-687.

Schul, P. L., Little, T. E., and Pride, W. (1985). “Channel Climate: It's Impact on Channel Members' Satisfaction," Journal of Retailing, 61(2), 9-38.

Shane, S. (1996), "Hybrid Organizational Arrangements and their Implications for Firm Growth and Survival: A Study of New Franchisors," Academy of Management Journal, 39(1), 216234.

Sillince, J., Jarzabkowski, P., and Shaw, D. (2010). "Shaping Strategic Action through the Rhetorical Construction and Exploitation of Ambiguity”, Organization Science, 23 (3), 630650.

Snijders, T. A. B., and Bosker, R. J. (1999). Multilevel Analysis: An Introduction to Basic and Advanced Multilevel Modeling. London, UK: Sage.

Sorenson, O., and Sorensen J. B. (2001). "Finding the Right Mix: Franchising, Organizational Learning, and Chain Performance,” Strategic Management Journal, 22(6/7), 713-724.

Strutton, D., Pelton, L. E., and Lumpkin, J. R. (1995). "Psychological Climate in Franchising System Channels and Franchisor-Franchisee Solidarity,” Journal of Business Research, 34(2), 81-91.

Stump, R. L., and Heide, J. B. (1996). “Controlling Supplier Opportunism in Industrial Relationships," Journal of Marketing Research, 33(November), 431-441.

Tracey, P., and Jarvis, O. (2007). "Toward a Theory of Social Venture Franchising," Entrepreneurship Theory \& Practice, 31(5), 667-685. 
Voss, Z. G., Voss, G. B., and Moorman, C. (2005). “An Empirical Examination of the Complex Relationships between Entrepreneurial Orientation and Stakeholder Support," European Journal of Marketing, 39(9/10), 1132-1150.

Wiklund, J. (1999), “The Sustainability of the Entrepreneurial Orientation-Performance Relationship," Entrepreneurship Theory and Practice, 24(1):37-48.

Wiklund, J., and Shepherd, D. (2005). "Entrepreneurial Orientation and Small Business Performance: A Configurational Approach,” Journal of Business Venturing, 20(1), 71-89. Williamson, O. E. (1975). Markets and Hierarchies. New York: Free Press. (1985). The Economic Institution of Capitalism. New York: Free Press. (1991). “Strategizing, Economizing, and Economic Organization," Strategic

Management Journal, 12 (Special Issue), 75-94. (2010). "Transaction Cost Economics: The Natural Progression," Journal of Retailing, 86(3), 215-226.

Windsperger, J., and Dant, R. (2006). "Contractibility and Ownership Redirection in Franchising: A Property Rights View," Journal of Retailing, 82(3), 259-272.

Yin, X., and Zajac, E. J. (2004). “The Strategy/Governance Structure Fit Relationship: Theory and Evidence in Franchising Arrangements," Strategic Management Journal, 25(4), 365-383.

Zhao, H., and Seibert, S. E. (2006). "The Big Five Personality Dimensions and Entrepreneurial Status: A Meta-Analytical Review," Journal of Applied Psychology, 91(2), 259-271. 
Table 1

Sample Characteristics

\begin{tabular}{lcc}
\hline Sector & $\begin{array}{c}\text { Number of Franchisees } \\
\text { in Sample }\end{array}$ & Percentage \\
\hline DIY/Home Improvement & 69 & 21.4 \\
Telecommunication/IT & 55 & 17.1 \\
Computer Hard-/Software & 51 & 15.9 \\
(Specialty) Food & 24 & 7.5 \\
Home Electronics & 17 & 5.4 \\
Insurance/Finance & 62 & 19.3 \\
Handcraft/Small Trade & 25 & 7.8 \\
Travel/Tourism & 18 & 5.6 \\
& & \\
Sum & $\mathbf{3 2 1}$ & $\mathbf{1 0 0 . 0}$ \\
\hline
\end{tabular}


Table 2

Psychometric Properties

\section{Level 1 Measures}

\begin{tabular}{lcccc}
\hline Opportunism & 1 & & & \\
Innovativeness & -.078 & 1 & & \\
Proactiveness & .010 & .088 & 1 & 1 \\
Risk Taking & .618 & -.101 & -.006 & \\
\hline & & & & .814 \\
Critical Ratio $(\boldsymbol{C R})$ & .978 & .819 & .833 & .525 \\
Average Variance Extracted $(\boldsymbol{A} \boldsymbol{V E})$ & .867 & .548 & .626 & \\
\hline
\end{tabular}

Level 2 Measures

\begin{tabular}{lccc}
\hline Information Exchange & 1 & & \\
Flexibility & $.363^{* *}$ & 1 & \\
Problem-Solving & $.176^{* *}$ & $.363^{* *}$ & 1 \\
\hline & & & \\
Critical Ratio $(\boldsymbol{C R})$ & .766 & .868 & .833 \\
Average Variance Extracted $(\boldsymbol{A} \boldsymbol{V E})$ & .526 & .688 & .555 \\
\hline
\end{tabular}


Table 3

HLM Results for Opportunism

\begin{tabular}{|c|c|c|c|}
\hline Predictor & $\begin{array}{c}\text { Unstandardized } \\
\text { Coefficient }\end{array}$ & t-ratio & sig.-level \\
\hline \multicolumn{4}{|c|}{ Level 1 (dependent variable OPP) } \\
\hline Innovativeness & .032 & .435 & $p>.1$ \\
\hline Proactiveness & .180 & 2.449 & $p<.01$ \\
\hline Risk Taking & .676 & 4.460 & $p<.001$ \\
\hline Franchisee Age & $-.591 * 10^{-3}$ & -4.917 & $p<.001$ \\
\hline \multicolumn{4}{|l|}{ Level 2 Intercept Effects } \\
\hline Age of Franchise System & .006 & .0166 & $p>.1$ \\
\hline Number of Franchisees in the & .158 & 2.930 & $p<.01$ \\
\hline \multicolumn{4}{|l|}{ System } \\
\hline Average System Success & .218 & .585 & $p>.1$ \\
\hline \multicolumn{4}{|l|}{ Level 2 Slope Effects } \\
\hline \multicolumn{4}{|l|}{ Innovativeness } \\
\hline Relational Contracting & .241 & 1.882 & $p<.1$ \\
\hline \multicolumn{4}{|l|}{ Proactiveness } \\
\hline Relational Contracting & .027 & .926 & $p>.1$ \\
\hline \multicolumn{4}{|l|}{ Risk Taking } \\
\hline Relational Contracting & .465 & 2.144 & $p<.05$ \\
\hline \multicolumn{4}{|l|}{ Franchisee Age } \\
\hline Relational Contracting & -.001 & -.708 & $p>.1$ \\
\hline
\end{tabular}


Figure 1

Conceptual Model

\begin{tabular}{|l|} 
Ex-Ante \\
\begin{tabular}{|l|}
\hline Entrepreneurial Characteristics \\
- $\quad$ Innovativeness \\
- $\quad$ Pisk-Taking \\
\hline
\end{tabular} \\
\hline
\end{tabular}

Franchisee

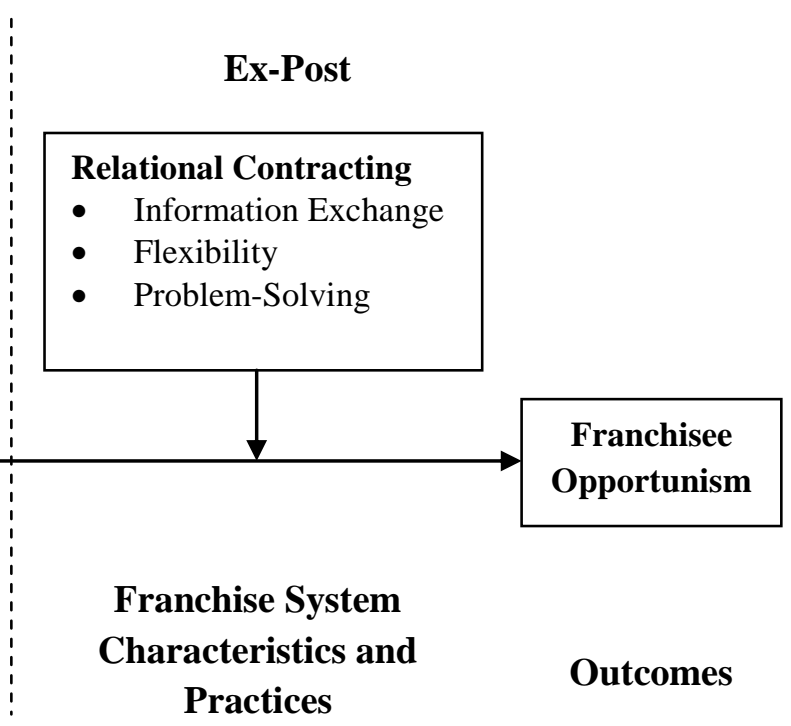




\title{
APPENDIX - QUESTIONNAIRE ITEMS
}

Entrepreneurial Characteristics (measures adapted from Jambulingam and Nevin 1999)

\author{
A. Innovativeness \\ (4 items, 5-point Likert Scale, "Strongly Disagree-Strongly Agree") \\ 1. Franchisees should provide leadership in new product development \\ 2 . The success of my franchise depends on constantly improving our products/services \\ 3 . Franchisees should provide leadership in new operating procedure development. \\ 4. In my franchise, we emphasize the promotion of new innovative products/services.
}

\section{B. Proactiveness}

(3 items, 5-point Likert Scale, "Strongly Disagree-Strongly Agree")

1. I look for challenges at work.

2. I think a lot about how to improve my chances for getting ahead.

3. I get a thrill out of confronting challenges at work.

\section{Business Risk-Taking}

(4 items, 5-point Likert Scale, "Strongly Disagree-Strongly Agree")

1. My business strategy is characterized by a strong tendency to undertake high risk projects.

2. A business should only take risks in areas that it knows well. (R)

3. Research is important before making a risky decision. (R)

4. I am a gambler-it is impossible to plan for the future.

\section{Franchisee Opportunism}

(7 items, 5-point Likert Scale, "Strongly Disagree-Strongly Agree")

1. I sometimes alter facts slightly in order to gain the cooperation of my franchisor

2. I sometimes explicitly promise to do things requested by my franchisor without actually doing them later.

3. I sometimes withhold information that would help my franchisor to run his business.

4. I do not always share information in a timely manner with my franchisor.

5. I sometimes make vague promises to my franchisor that I later ignore.

6. I sometimes purposely withhold information that would put me in a bad light.

7. I sometimes tell my franchisor what I think he wants to hear instead of telling him the truth. 


\section{APPENDIX - QUESTIONNAIRE ITEMS (cont.)}

Relational Contracting (Jambulingam and Nevin 1999)

(10 items, 5-point Likert Scale, "Strongly Disagree-Strongly Agree")

\section{A. Information Exchange}

1. Exchange of information in this relationship takes place frequently and informally and not only according to prespecified agreement.

2. In our relationship, it is expected that any information that might help the other party will be provided to them.

3. In this relationship, it is expected that parties will provide confidential information if it can help the other party.

\section{B. Flexibility}

1. Flexibility in response to requests for changes is a characteristics of our relationship.

2. The ability to make adjustments in order to cope with changing circumstances is a characteristic of our relationship.

3. My franchisor and I are open to modifying our agreements if unexpected events occur.

\section{Problem Solving}

1. When problems occur, I can easily find a mutually agreeable solution with my franchisor.

2. My franchisor always makes an honest attempt to work out problems between us.

3. My franchisor is very unwilling to settle disputes with me $(\mathrm{R})$

4. Disagreements with my franchisor are usually solved by one-sided, "take it or leave it" solutions proposed by the franchisor $(\mathrm{R})$

\section{Success of the Franchise System}

(3 items, 5-point Likert Scale, "Strongly Disagree-Strongly Agree")

1. In all, the franchise system has been very successful in the past 3 years.

2. Compared to our competition, we have been very successful.

3. We have achieved our goals in terms of financial success. 